\title{
Dynamics of bacterial metabolic profile and community structure during the mineralization of organic carbon in intensive swine farm wastewater
}

\author{
Xiaoyan Ma ${ }^{1}$, Ming Liu ${ }^{1}$, and Zhongpei $\mathrm{Li}^{{ }^{*}}$
}

Land application of intensive swine farm wastewater has raised serious environmental concerns due to the accumulation and microbially mediated transformation of large amounts of swine wastewater organic C (SWOC). Therefore, the study of SWOC mineralization and dynamics of wastewater microorganisms is essential to understand the environmental impacts of swine wastewater application. We measured the $\mathrm{C}$ mineralization of incubated swine wastewaters with high (wastewater $\mathrm{H}$ ) and low (wastewater L) organic C concentrations. The dynamics of bacteria metabolic profile and community structure were also investigated. The results showed that SWOC mineralization was properly fitted by the two-simultaneous reactions model. The initial potential rate of labile $\mathrm{C}$ mineralization of wastewater $\mathrm{H}$ was $46 \%$ higher than that of wastewater $\mathrm{L}$, whereas the initial potential rates of recalcitrant $\mathrm{C}$ mineralization of wastewaters $\mathrm{H}$ and L were both around $23 \mathrm{mg} \mathrm{L}^{-1} \mathrm{~d}^{-1}$. The bacterial functional and structural diversities significantly decreased for both the wastewaters during SWOC mineralization, and were all negatively correlated to specific UV absorbance $\left(\mathrm{SUVA}_{254} ; P<0.01\right)$. The bacteria in the raw wastewaters exhibited functional similarity, and both metabolic profile and community structure changed with the mineralization of SWOC, mainly under the influence of $\mathrm{SUVA}_{254}(P<0.001)$. These results suggested that SWOC mineralization was characterized by rapid mineralization of labile $\mathrm{C}$ and subsequent slow decomposition of recalcitrant $\mathrm{C}$ pool, and the quality of SWOC varied between the wastewaters with different amounts of organic $\mathrm{C}$. The decreased bio-availability of dissolved organic matter affected the dynamics of wastewater bacteria during SWOC mineralization.

Key words: Carbon mineralization, community level physiological profiles, denaturing gradient gel electrophoresis, SUVA $_{254}$, swine wastewater organic carbon.

\section{INTRODUCTION}

Intensive swine industry has rapidly developed in the past few years (Deng et al., 2007; Bernet and Béline, 2009; Girard et al., 2009; Fernandes et al., 2012) and generates large amounts of excrements and wastewater in concentrated areas. One of the most common waste management practices is the land application of swine wastewater as fertilizer or, in some regions, discharge of wastewater to nearby fields and water bodies after simple treatment (Zhou et al., 2013). The high concentration of organic matter $(\mathrm{OM})$ in swine wastewater exceeds the carrying capacity of the environment (González et al., 2008), and has raised serious environmental concerns about livestock farms (Deng et al., 2008).

The application of livestock farming wastewater could increase soil organic $\mathrm{C}$ and microbial biomass (Adeli et al., 2008), as well as immediately increase soil respiration (Fangueiro et al., 2012). However, little attention has been

${ }^{1}$ Chinese Academy of Sciences, Institute of Soil Science, 71 East Beijing Road, Nanjing 210008, P.R. China.

*Corresponding author (zhpli@issas.ac.cn).

Received: 13 August 2014.

Accepted: 23 March 2015.

doi:10.4067/S0718-58392015000200012 paid to the mineralization of swine wastewater organic $\mathrm{C}$ (SWOC), which could be quite distinctive owing to the abundant organic $\mathrm{C}$ in swine wastewater, when compared with that in natural bodies of water. Therefore, the study of SWOC mineralization is fundamental to understand the effect of wastewater application on the dynamics of organic $\mathrm{C}$ in soil or aquatic ecosystems. Mineralization is driven by microorganisms. The composition of livestock wastewater microbial community has been repeatedly emphasized in different contexts such as swine sewage lagoons (Cook et al., 2010), bioreactors (Mota et al., 2005; Patil et al., 2010), and constructed wetlands (Ibekwe et al., 2003). However, with the purpose of efficiently removing surplus nutrients and hazardous compounds, the environmental conditions in artificial ecosystems are frequently adjusted to promote the growth of particular functional microflora (Kim et al., 2010), which alters the microbial community from its natural state. Furthermore, the application of raw and decomposed wastewater could cause different effects on soil microbial community (Walsh et al., 2012), and the difference might be partly attributed to the inoculation effect of changed wastewater microorganisms during SWOC mineralization (GarcíaGil et al., 2000). Therefore, the study of the response of wastewater microorganisms to SWOC mineralization could contribute to the understanding of the dynamics and 
duration of the effects of wastewater application on the microbial communities in other environments.

The aim of the present study was to characterize the mineralization of SWOC, examine the responses of bacterial community, and detect the driving factors. Community level physiological profiles (CLPP) and denaturing gradient gel electrophoresis (DGGE) techniques were applied to examine the dynamics of bacteria in two types of wastewaters with different concentrations of OM. We hypothesized that SWOC mineralization could be divided into mineralization of two $\mathrm{C}$ pools, namely, a labile fraction and a recalcitrant pool, and that the bacterial community will shift throughout the mineralization of SWOC, mainly under the influence of C availability.

\section{MATERIALS AND METHODS}

\section{Site description and wastewater sampling}

Wastewater samples were collected from the draining outlets of two swine farms located in Yujiang County, Jiangxi Province, China. The county is characterized by a subtropical monsoon climate with a mean annual temperature of $17.6{ }^{\circ} \mathrm{C}$, an annual rainfall of $1789 \mathrm{~mm}$, and a frost-free period of $258 \mathrm{~d}$. Over 400 swine farms with a total wastewater output of approximately $1.79 \times$ $10^{6} \mathrm{t}$ (Zhou et al., 2013) were distributed across an area of $936 \mathrm{~km}^{2}$, of which $34 \%$ were used as farmland and $10 \%$ were water area. The number of pigs for most swine farms in this area was between 2000-5000 heads, thus the farm Baita (2812'5" N, 116 54'24" E) with 4000 pigs was chosen to represent the typical swine farms in Yujiang. Since most farms shared the same pig breed and fodder, the number of pigs became a main factor that affected the characteristics of wastewater. Therefore, to gain a better understanding of SWOC mineralization, we also picked the largest local swine farm Wangu $\left(28^{\circ} 6^{\prime} 17^{\prime \prime} \mathrm{N}\right.$, $116^{\circ} 53$ '14" E) (20 000 pigs). As assumed, the large farm produced much more concentrated wastes, and dealing with these wastes generated $\mathrm{C}$ and $\mathrm{N}$ enriched wastewater (wastewater $\mathrm{H}$ ) containing higher concentrations of nutrients than wastewater (wastewater L) from typical swine farm (Table 1).

\section{Incubation, mineralization, and chemical properties of SWOC}

A total of $100 \mathrm{~mL}$ of each type of wastewater were added into $250-\mathrm{mL}$ triangular flasks after the removal

Table 1. Physical and chemical characteristics of wastewaters $\mathbf{H}$ and $\mathbf{L}$.

\begin{tabular}{lrrrrrrrr}
\hline Sample & $\mathrm{pH}$ & $\mathrm{EC}$ & $\mathrm{NH}_{4}{ }^{+}-\mathrm{N}$ & $\mathrm{NO}_{3}{ }^{-}-\mathrm{N}$ & $\mathrm{TDN}$ & $\mathrm{SP}$ & DOC & TOC \\
\hline \multicolumn{7}{c}{$\mathrm{ms} \mathrm{cm}^{-1}$} & & \multicolumn{7}{c}{$\mathrm{mg} \mathrm{L}^{-1}$} \\
$\mathrm{H}$ & 7.99 & 15.60 & 661.53 & 1.90 & 1368.97 & 78.76 & 1845.64 & 2937.77 \\
$\mathrm{~L}$ & 7.66 & 4.69 & 300.08 & 0.73 & 402.75 & 40.41 & 634.79 & 993.60
\end{tabular}

$\mathrm{H}$ : wastewater with high concentration of organic $\mathrm{C}$; $\mathrm{L}$ : wastewater with low concentration of organic C; EC: electrical conductivity; TDN: total dissolved $\mathrm{N}$; SP: soluble P; DOC: dissolved organic C; TOC: total organic C. of floating debris and sediments. The flasks were sealed with polytetrafluoroethylene films with filtering membrane in the center to allow air exchange, and then incubated at $28{ }^{\circ} \mathrm{C}$ for $60 \mathrm{~d}$. The water lost through evaporation was replenished every week by measuring the total weight loss.

Mineralization was determined by measuring the evolved $\mathrm{CO}_{2}$ in another set of triangular flasks. A $10-\mathrm{mL}$ glass vial filled with $5 \mathrm{~mL}$ of $1.0 \mathrm{M} \mathrm{NaOH}$ was placed in a 250-mL airtight flask to trap the $\mathrm{CO}_{2}$. The unreacted $\mathrm{NaOH}$ was back-titrated with standard $\mathrm{HCl}$ after the precipitation of carbonate with $1.0 \mathrm{M} \mathrm{BaCl} 2$. Mineralization was monitored daily for the first $16 \mathrm{~d}$ and at other required time intervals (each time, the flask was opened for $30 \mathrm{~min}$ to allow air exchange before replenishing with $\mathrm{NaOH}$ ). Based on the $\mathrm{CO}_{2}-\mathrm{C}$ production rate, six bottles of each wastewater were sampled at the initial $(0 \mathrm{~d})$, transitional (14 d and $25 \mathrm{~d}$ ) and terminal stages (60 d) of SWOC mineralization, respectively. The samples were divided into two groups for chemical and microbial analyses.

The wastewaters sampled at different mineralization stages were filtered through pre-combusted Whatman $\mathrm{GF} / \mathrm{F}$ glass fiber filters. The dissolved organic C (DOC) and total dissolved $\mathrm{N}$ (TDN) were measured by Jena 3100c total organic C (TOC) analyzer with total $\mathrm{N}$ unit (Analytik Jena AG, Jena, Germany). UV absorbance at $254 \mathrm{~nm}$ was determined by Shimadzu UV 2450 (Shimadzu, Kyoto, Japan) and used for the calculation of specific UV absorbance $\left(\mathrm{SUVA}_{254}\right)$ according to the formula SUVA $254\left(\mathrm{~L} \mathrm{mg}^{-1} \mathrm{~m}^{-1}\right)=\mathrm{UV}_{254} / \mathrm{DOC}$ (Weishaar et al., 2003). Soluble P (SP) was measured by colorimetric method (Murphy and Riley, 1962). The wastewater $\mathrm{pH}$ was also measured.

\section{Community level physiological profiles (CLPP)}

After vortexing, $1 \mathrm{~mL}$ of wastewater was diluted to $1 \%$ with sterile $0.85 \% \mathrm{NaCl}$ solution. Next, $150 \mu \mathrm{L}$ of each sample were inoculated into the wells of Biolog EcoPlate (Biolog Inc., Hayward, California, USA). The plates were read immediately using a plate reader at $590 \mathrm{~nm}$, and then incubated at $25^{\circ} \mathrm{C}$ for $240 \mathrm{~h}$. The absorbance was measured every $24 \mathrm{~h}$.

\section{Denaturing gradient gel electrophoresis (DGGE)}

DNA was obtained by first filtering $5 \mathrm{~mL}$ of wastewater through a sterile mixed cellulose esters membrane with a pore size of $0.45 \mu \mathrm{m}$ (EMD Millipore, Darmstadt, Germany) to intercept the microorganisms. The membrane was then put into a 5-mL beating tube and DNA was extracted using the method of PowerWater DNA isolation kit (MO BIO Laboratories Inc, Carlsbad, California, USA). For the DGGE analysis of $16 \mathrm{~S}$ rDNA gene fragments, the bacterial primers $341-\mathrm{F}-\mathrm{GC}\left(5^{\prime}\right.$-CGCCCG CCGCGCCCCGCGCCCGTCCCGCCGCCCCCGCCC GCCTACGGGAGGCAGCAG-3') (Muyzer, et al., 1993; 1998) and 907-R (5'-CCGTCAATTCCTTTGAGTTT-3') 
were used (Muyzer et al., 1995). PCR was performed with a $25 \mu \mathrm{L}$ reaction mixture containing $12.5 \mu \mathrm{L}$ of Premix Taq (TaKaRa Bio Inc., Otsu, Japan), $0.25 \mu \mathrm{L}$ of each primer at a concentration of $20 \mu \mathrm{M}, 0.5 \mu \mathrm{L}$ of template, and $11.5 \mu \mathrm{L}$ of sterile distilled deionized water. Thermocycling was conducted on a TaKaRa PCR Thermal Cycler Dice TP600 (TaKaRa Bio Inc.) under the following conditions: initial denaturation at $95{ }^{\circ} \mathrm{C}$ for 5 min, 30 cycles at $94{ }^{\circ} \mathrm{C}$ for $45 \mathrm{~s}, 55^{\circ} \mathrm{C}$ for $45 \mathrm{~s}$, and 72 ${ }^{\circ} \mathrm{C}$ for $45 \mathrm{~s}$, followed by a final primer extension at $72{ }^{\circ} \mathrm{C}$ for $10 \mathrm{~min}$. The denaturing gradient was $45 \%$ to $70 \%$ in a $6 \%$ polyacrylamide gel. DGGE was performed using a DGGEK-2401 electrophoresis system (C.B.S. Scientific, San Diego, California, USA) in $1 \times$ TAE buffer at 60 ${ }^{\circ} \mathrm{C}$ and $70 \mathrm{~V}$ for $15 \mathrm{~h}$. After electrophoresis, the gel was stained with GelRed ${ }^{\mathrm{TM}}$ (Biotium, Hayward, California, USA) and photographed by Gel Doc XR+ System (BioRad, Hercules, California, USA).

\section{Data analyses}

The $\mathrm{C}$ mineralization in swine wastewater was fitted according to the two-simultaneous reactions model as follows: $C_{t}=C_{1}\left(1-e^{-k_{1} t}\right)+C_{2}\left(1-e^{-k_{2} t}\right)$ where $\mathrm{C}_{\mathrm{t}}$ is the cumulative $\mathrm{C}$ mineralized after time $\mathrm{t}\left(\mathrm{mg} \mathrm{L}^{-1}\right)$ and $\mathrm{C}_{1}$ and $\mathrm{C}_{2}$ represent the labile and recalcitrant $\mathrm{C}$ pools $\left(\mathrm{mg} \mathrm{L}^{-1}\right)$ mineralized at the rates of $k_{1}$ and $k_{2}\left(\mathrm{~d}^{-1}\right)$, respectively (Molina et al., 1980). The average well color development (AWCD), Shannon-Weaver index ( $\left.\mathrm{H}^{\prime}\right)$, and Simpson's diversity index (D) of the $168 \mathrm{~h}$ CLPP data were calculated after subtracting the absorbance of the control well from the other 31 wells. In addition, the well absorbance was standardized by dividing its corresponding AWCD before ordination analysis. The bands in the DGGE fingerprint were matched and quantified by Quantity One (version 4.62; Bio-Rad, Hercules, California, USA), and then used for $\mathrm{H}^{\prime}$ and $\mathrm{D}$ calculation and subsequent ordination analysis.

Two methods were adopted for the ordination analysis of CLPP and DGGE profiles. First, nonmetric multidimensional scaling (NMDS) was

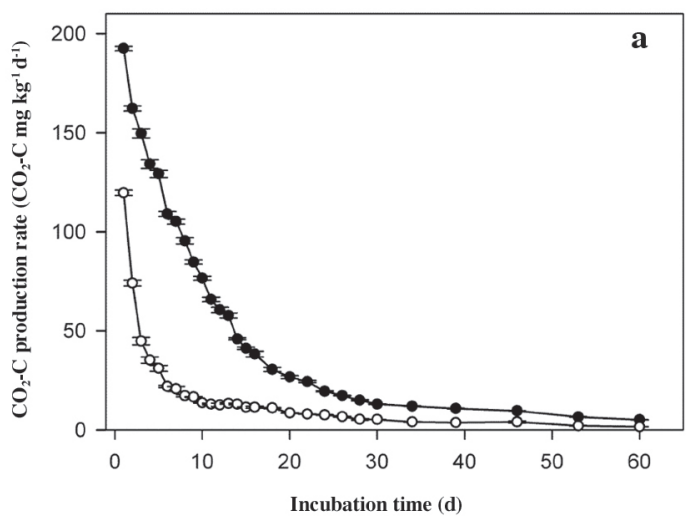

performed based on Bray-Curtis distances of the standardized absorbance and band data. Subsequently, a parsimonious canonical correspondence analysis (CCA) was conducted to investigate the relationships between microbial communities and environmental factors, including $\mathrm{pH}, \mathrm{DOC}, \mathrm{SUVA}_{254}, \mathrm{TDN}, \mathrm{SP}$, and $\mathrm{C} / \mathrm{N}$ ratio $(\mathrm{C} / \mathrm{N})$. Although the explained inertia decreases in the parsimonious CCA, it produces a much clearer and stable model that is easy to interpret (Borcard et al., 2011). The parsimonious CCA was computed based on mantel test, and environmental factors that significantly correlated to species matrix were first selected for CCA. Then, the variance inflation factor (VIF) of each selected factor was calculated and one with the maximum VIF was removed in the subsequent CCA. The last procedure was repeated until the VIFs of all the remaining factors were less than 2. Ordination analysis was conducted by using R (version 3.0.0; R Development Core Team) with the vegan package. The diversity indices and chemical properties were submitted to one-way ANOVA, followed by a post-hoc of Duncan $(P<0.05)$ as well as Pearson two-tailed correlation analysis using SPSS (version 18.0.0; IBM, Armonk, New York, USA).

\section{RESULTS}

\section{SWOC mineralization and chemical properties}

SWOC mineralization could be divided into three stages based on the $\mathrm{CO}_{2}-\mathrm{C}$ production rate (Figure 1a). The initial stage was characterized by a linear decrease in the $\mathrm{CO}_{2}-\mathrm{C}$ production rate, which was followed by the transitional stage with a smooth turning point and the terminal stage with almost steady $\mathrm{CO}_{2}-\mathrm{C}$ production rate approaching zero. The mineralization processes of the two wastewaters were inconsistent, which were reflected by the longer initial and transitional stages of wastewater $\mathrm{H}$, when compared with those of wastewater L. The initial $\mathrm{CO}_{2}-\mathrm{C}$ production rate of wastewater $\mathrm{H}$ was $192.51 \mathrm{mg} \mathrm{L}^{-1} \mathrm{~d}^{-1}$, which was $62 \%$ higher than that of wastewater L (119.04 $\left.\mathrm{mg} \mathrm{L}^{-1} \mathrm{~d}^{-1}\right)$.

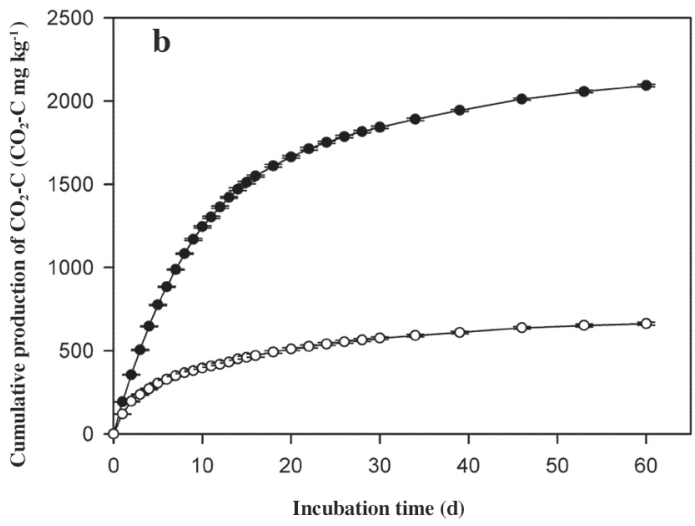

Figure 1. $\mathrm{CO}_{2}-\mathrm{C}$ production rate (a) and cumulative production of $\mathrm{CO}_{2}-\mathrm{C}(\mathrm{b})$ for high organic $\mathrm{C}$ concentration wastewater ( $)$ and low organic C concentration wastewater $(0)$. 
The cumulative productions of $\mathrm{CO}_{2}-\mathrm{C}$ of wastewaters $\mathrm{H}$ and $\mathrm{L}$ were 2093.22 and $662.23 \mathrm{mg} \mathrm{L}^{-1}$, respectively (Figure 1b). The characteristics of SWOC mineralization were appropriately outlined by the two-simultaneous reactions model (Table 2). For wastewater $\mathrm{H}, 65 \%$ of the potentially mineralizable $\mathrm{C}\left(\mathrm{C}_{1}+\mathrm{C}_{2}\right)$ comprised the labile pool, whereas wastewater $\mathrm{L}$ was characterized by a larger proportion of recalcitrant $\mathrm{C}(69 \%)$. The mineralization rate constants of both the $\mathrm{C}$ pools in wastewater $\mathrm{L}$ were higher than those of wastewater $\mathrm{H}$. The initial potential rates of labile $\mathrm{C}$ mineralization $\left(C_{l} k_{l}\right)$ for both the wastewaters were approximately equal to their individual initial mineralization rates (Figure 1a), with the value for wastewater $\mathrm{H}\left(58 \mathrm{mg} \mathrm{L}^{-1} \mathrm{~d}^{-1}\right)$ being higher than that for wastewater L. However, the initial potential rates of recalcitrant $\mathrm{C}$ mineralization $\left(C_{2} k_{2}\right)$ for both the wastewaters were around $23 \mathrm{mg} \mathrm{L}^{-1} \mathrm{~d}^{-1}$.

The DOC and TDN declined steadily throughout $\mathrm{C}$ mineralization and their losses were $78 \%$ and $67 \%$ for wastewater $\mathrm{H}$ and $91 \%$ and $63 \%$ for wastewater $\mathrm{L}$, respectively (Table 3). On the contrary, SUVA $_{254}$ kept increasing within the range from 0.85 to 2.82 . Although the initial values of $\mathrm{SUVA}_{254}$ of the two types of wastewaters were close, by the end of the mineralization process, the $\mathrm{SUVA}_{254}$ of wastewater L was significantly higher than that of wastewater $\mathrm{H}$. The dynamics of $\mathrm{C} / \mathrm{N}$ were not in accordance with that of $\mathrm{C}$ and $\mathrm{N}$ as a result of the variance in their degradation. With regard to wastewater $\mathrm{H}$, the $\mathrm{C} / \mathrm{N}$ started to decrease since $0 \mathrm{~d}$, but increased at the end, whereas for wastewater $\mathrm{L}$, the $\mathrm{C} / \mathrm{N}$ was initially higher and fluctuated during incubation, but was lower by 0.51 than that of wastewater $\mathrm{H}$ after $60 \mathrm{~d}$; besides, maximum $\mathrm{C} / \mathrm{N}$ was observed at the beginning of SWOC mineralization. The $\mathrm{pH}$ of both types of wastewaters increased during the transitional stage, but significantly decreased during the

Table 2. Parameter estimates according to the two-simultaneous reactions model for swine wastewater organic $C$ (SWOC) mineralization.

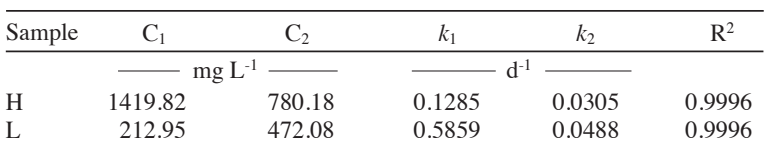

$\mathrm{H}$ : wastewater with high concentration of organic $\mathrm{C}$; $\mathrm{L}$ : wastewater with low concentration of organic $\mathrm{C} ; \mathrm{C}_{1}$ and $\mathrm{C}_{2}$ : labile and recalcitrant organic $\mathrm{C}$, respectively; $k_{1}$ and $k_{2}$ : rate constant of labile and recalcitrant organic $\mathrm{C}$, respectively. terminal stage, and the difference in the $\mathrm{pH}$ of the two types of wastewaters increased to 2 units at the end of incubation.

\section{Dynamics of wastewater bacterial metabolic profile}

The AWCD and functional diversity indices $\left(\mathrm{H}^{\prime}\right.$ and $\left.\mathrm{D}\right)$ decreased by the end of SWOC mineralization (Figure 2). For both samples, AWCD decreased significantly at each stage. Although AWCD of wastewater H (0.91) was higher than that of wastewater $\mathrm{L}(0.73)$ at the initial stage, it decreased by 0.76 , when compared with that for the latter (0.45). The two types of wastewaters had approximately similar diversity indices initially, but then exhibited distinct trends. With regard to wastewater $\mathrm{H}$, the two indices continued to drastically decrease during incubation. However, the $\mathrm{H}^{\prime}$ of wastewater $\mathrm{L}$ decreased steadily throughout SWOC mineralization, whereas the D was stable with just a slight decrease of 0.02. Correlation analysis indicated that $\mathrm{SUVA}_{254}$ correlated negatively $(P$ $<0.01)$ to the AWCD and diversity indices.

Similar to the dynamics of the functional diversity indices, the initial microbial metabolic profiles of both the types of wastewaters were similar and then differed from each other progressively (Figure 3). The microbial metabolic profiles of both the types of wastewaters varied between the mineralization stages. The SUVA 254 $(r=0.3988, P<0.001)$ and $\mathrm{pH}(r=0.3074, P=0.015)$

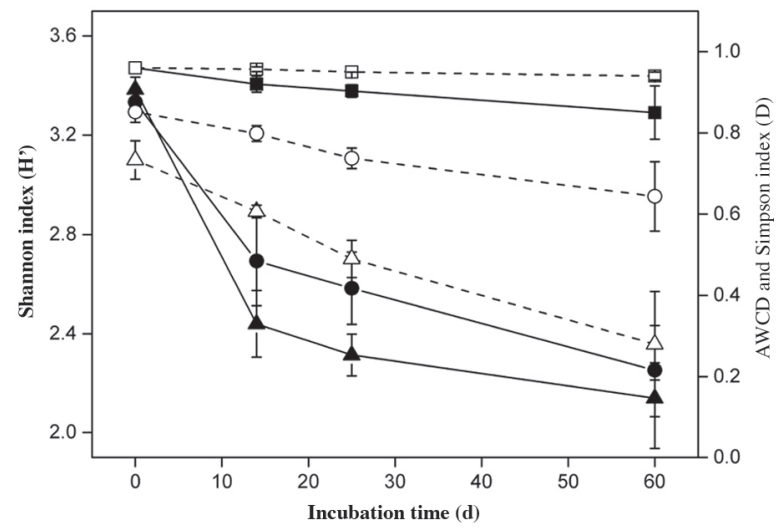

Figure 2. The average well color development (AWCD) $(\boldsymbol{\Delta}, \triangle)$, Shannon index $(\bullet, \circ)$, and $\operatorname{Simpson} \operatorname{index}(\square, \square)$ for the microbial metabolic profiles (mean \pm standard deviation, $n=3$ ) in high (closed symbol) and low organic $\mathbf{C}$ concentration wastewater (open symbol) on $0,14,25$, and $60 \mathrm{~d}$ of swine wastewater organic $\mathrm{C}$ (SWOC) mineralization.

Table 3. Chemical characteristics of the swine wastewaters during swine wastewater organic C (SWOC) mineralization.

\begin{tabular}{|c|c|c|c|c|c|}
\hline Sample & DOC & SUVA $_{254}$ & TDN & $\mathrm{C}: \mathrm{N}$ & $\mathrm{pH}$ \\
\hline & $\mathrm{mg} \mathrm{L}^{-1}$ & & $\mathrm{mg} \mathrm{L}^{-1}$ & & \\
\hline $\mathrm{HO}$ & $1845.64 \pm 23.49 a$ & $0.87 \pm 0.01 \mathrm{a}$ & $1368.97 \pm 8.53 \mathrm{a}$ & $1.57 \pm 0.01 \mathrm{a}$ & $7.99 \pm 0.02 \mathrm{a}$ \\
\hline $\mathrm{H} 14$ & $709.94 \pm 6.61 b$ & $1.74 \pm 0.02 b$ & $1083.59 \pm 20.44 b$ & $0.77 \pm 0.03 b$ & $9.04 \pm 0.02 b$ \\
\hline $\mathrm{H} 25$ & $543.78 \pm 22.39 c$ & $2.20 \pm 0.06 \mathrm{c}$ & $1048.84 \pm 28.48 b$ & $0.61 \pm 0.03 c$ & $9.31 \pm 0.01 c$ \\
\hline H60 & $400.51 \pm 8.61 d$ & $2.53 \pm 0.04 d$ & $446.67 \pm 15.52 c$ & $1.05 \pm 0.03 \mathrm{~d}$ & $8.47 \pm 0.27 \mathrm{~d}$ \\
\hline L0 & $634.79 \pm 29.35 \mathrm{e}$ & $0.85 \pm 0.03 \mathrm{a}$ & $402.75 \pm 18.54 c$ & $1.84 \pm 0.01 \mathrm{e}$ & $7.66 \pm 0.01 \mathrm{e}$ \\
\hline L14 & $149.56 \pm 5.76 \mathrm{f}$ & $1.43 \pm 0.04 \mathrm{e}$ & $351.25 \pm 19.62 d$ & $0.50 \pm 0.07 f$ & $9.06 \pm 0.01 b$ \\
\hline L25 & $110.63 \pm 0.6 \mathrm{~g}$ & $1.56 \pm 0.02 f$ & $159.28 \pm 7.01 \mathrm{e}$ & $0.81 \pm 0.04 \mathrm{~b}$ & $8.93 \pm 0.02 b$ \\
\hline L60 & $55.97 \pm 3.12 \mathrm{~h}$ & $2.82 \pm 0.13 g$ & $119.87 \pm 5.3 \mathrm{e}$ & $0.54 \pm 0.01 \mathrm{f}$ & $6.44 \pm 0.21 f$ \\
\hline
\end{tabular}

Values reported as means \pm standard deviation $(\mathrm{n}=3)$. Different letters indicate significant differences between the samples $(P<0.05)$.

$\mathrm{H} 0, \mathrm{H} 14, \mathrm{H} 25$, and H60: wastewater H on 0, 14, 25, and $60 \mathrm{~d}$ of SWOC mineralization, respectively; L0, L14, L25, and L60: wastewater L on 0, 14, 25, and 60 d of SWOC mineralization, respectively; DOC: dissolved organic C; SUVA 254 : specific UV absorbance at $254 \mathrm{~nm}$; TDN: total dissolved N. 


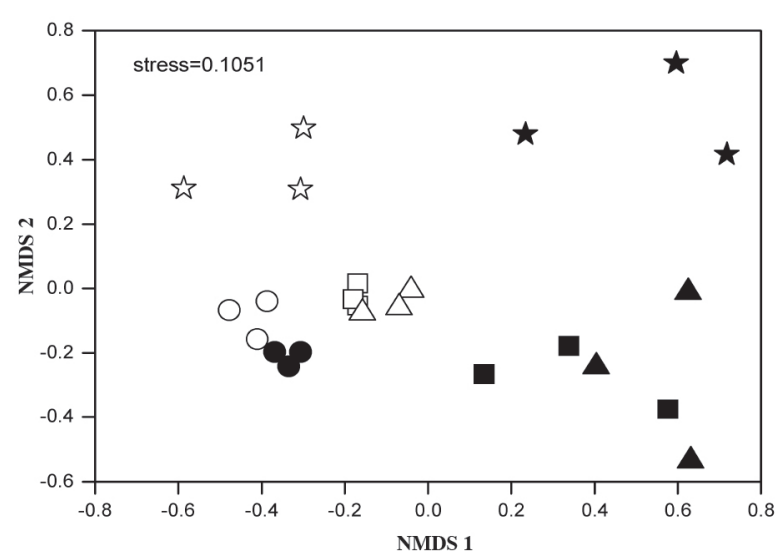

Figure 3. Non-metric multidimensional scaling (NMDS) analysis of the microbial metabolic profiles in high (closed symbol) and low organic $C$ concentration wastewater (open symbol) on $0(\bullet, \circ), 14$ $(\square, \square), 25(\Delta, \triangle)$, and $60(\star, \star \star))$ d of swine wastewater organic $C$ (SWOC) mineralization.

were selected for parsimonious CCA (Figure 4). The sample points representing different microbial metabolic profiles in each mineralization stage were distributed along the two vectors, especially along SUVA 254 . Both $\mathrm{pH}$ and $\mathrm{SUVA}_{254}$ were noted to be the fundamental factors controlling the dynamics of swine wastewater microbial metabolic profile.

\section{Dynamics of wastewater bacterial community structure}

Despite several fluctuations, the diversity of wastewater bacterial community exhibited a downtrend throughout the SWOC mineralization process (Figure 5). For wastewater $\mathrm{H}$, both the indices slightly increased at the terminal stage. For wastewater $\mathrm{L}$, the $\mathrm{H}^{\prime}$ increased on $25 \mathrm{~d}$ but eventually decreased. The D declined smoothly during the first $25 \mathrm{~d}$, followed by a significant decrease at the terminal stage. Correlation analyses revealed that the

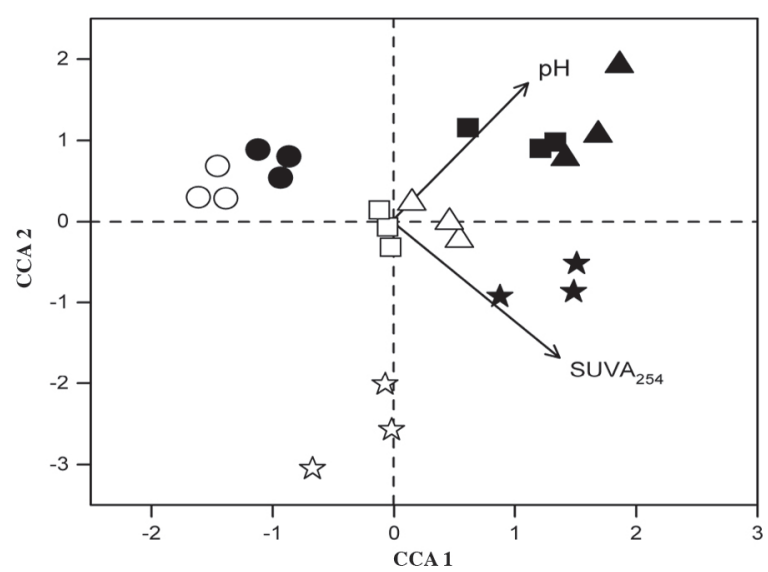

Figure 4. Parsimonious canonical correspondence analysis (CCA) of selected environmental factors (arrows) and microbial metabolic profiles in high (closed symbol) and low organic $\mathrm{C}$ concentration wastewater (open symbol) on $0(\bullet, \circ), 14(\square, \square), 25(\Delta, \triangle)$, and 60 $(\star, \star \star)) \mathrm{d}$ of swine wastewater organic C (SWOC) mineralization.

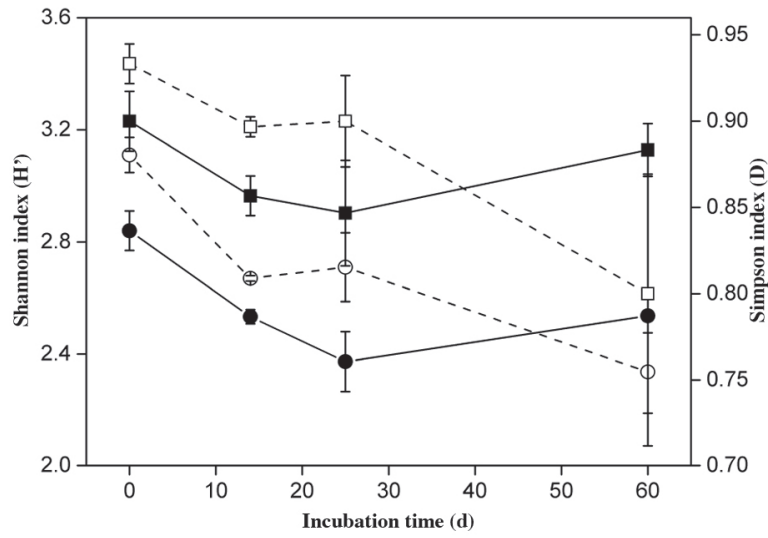

Figure 5. The Shannon index $(\bullet, \circ)$ and $\operatorname{Simpson}$ index $(\bullet, \square)$ for the bacterial communities (mean \pm standard deviation, $n=3$ ) in high (closed symbol) and low organic $C$ concentration wastewater (open symbol) on $0,14,25$, and $60 \mathrm{~d}$ of swine wastewater organic $\mathrm{C}$ (SWOC) mineralization.

diversity indices were negatively correlated to $\mathrm{SUVA}_{254}$ $(P<0.01)$, but positively correlated to $\mathrm{C} / \mathrm{N}(P<0.01)$.

Unlike the metabolic profile, the bacterial community structures of the two types of wastewaters varied sharply from each other at the beginning of SWOC mineralization, and the difference was increased along the process. With regard to wastewater $\mathrm{H}$, at the transitional stage, the bacterial community structure seemed to have already reached a relatively stable state, which led to adjacent sample dots of the last two mineralization stages (Figure 6). Three factors including TDN $(r=0.475, P<0.001)$, SUVA $_{254}(r=0.4298, p<0.001)$, and pH $(r=0.2666$, $p<0.001$ ) were selected for parsimonious CCA (Figure 7). Among these three factors, SUVA $_{254}$ exhibited the highest correlation with CCA 1, while TDN was strongly correlated to CCA 2. As the explained variances for both axes were close, both SUVA $_{254}$ and TDN acted as driving factors.

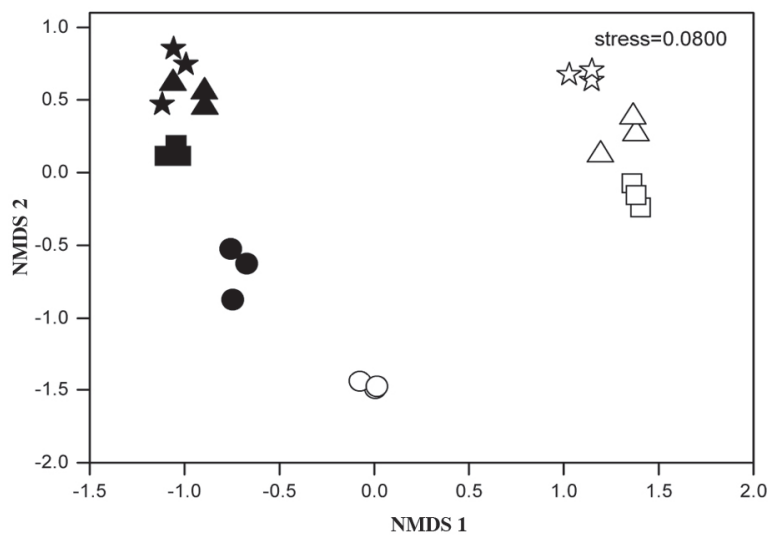

Figure 6. Non-metric multidimensional scaling (NMDS) analysis of the bacterial communities in high (closed symbol) and low organic $\mathrm{C}$ concentration wastewater (open symbol) on $0(\bullet, \circ), 14(\boxminus, \square), 25$ $(\Delta, \triangle)$, and $60(\star, \star))$ d of swine wastewater organic $\mathbf{C}$ (SWOC) mineralization. 


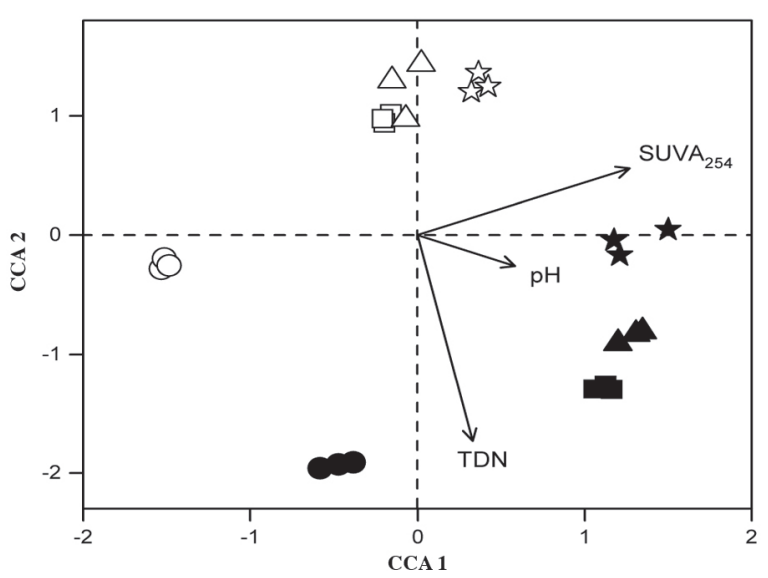

Figure 7. Parsimonious canonical correspondence analysis (CCA) of selected environmental factors (arrows) and bacterial communities in high (closed symbol) and low organic $\mathrm{C}$ concentration wastewater (open symbol) on $0(\bullet, \circ), 14(\square, \square), 25(\Delta, \triangle)$, and $60(\star, \star \star)$ d of swine wastewater organic C (SWOC) mineralization.

\section{DISCUSSION}

A previous study indicated that the release of SWOC is primarily in the form of $\mathrm{CO}_{2}$ rather than $\mathrm{CH}_{4}$ (Dinuccio et al., 2008). Hence, mineralization is a crucial pathway for SWOC transformation. The mineralization process was most active during the initial stage of SWOC decomposition owing to the preferential mineralization of labile $\mathrm{C}$, including large amounts of carbohydrates (Gigliotti et al., 2002). With the depletion of labile C and increase in recalcitrant $\mathrm{C}$, the intensity of mineralization subsided and gradually became steady. The mineralization dynamics of SWOC varied remarkably between the two types of wastewaters with different organic $\mathrm{C}$ concentrations, and a much higher level of mineralizable $\mathrm{C}$ was observed in wastewater $\mathrm{H}$ owing to its higher $\mathrm{C}_{1}$ and $\mathrm{C}_{2}$. Regardless of higher $k_{1}$ for wastewater L, the labile $\mathrm{C}$ in wastewater $\mathrm{H}$ appeared to be more bioavailable, as evidenced by the higher value of $C_{l} k_{1}$, a more accurate indicator of $\mathrm{C}$ quality (Fernández et al., 2007). Furthermore, mineralization of SWOC led to a significant increase in $\mathrm{SUVA}_{254}$, which reflects the aromaticity of DOC (Chin et al., 1997; Weishaar et al., 2003). This increase could probably be owing to the humidification process during incubation (Pajączkowska et al., 2003), and higher $\mathrm{SUVA}_{254}$ at the end of SWOC mineralization for wastewater $\mathrm{H}$ could be attributed to its larger amount of recalcitrant $\mathrm{C}$.

The functional diversity of swine wastewater microorganisms and their $\mathrm{C}$ utilization ability diminished along with the decrease in the $\mathrm{CO}_{2}$ production rate during SWOC mineralization. The decline in AWCD was probably owing to the decreased bio-availability of $\mathrm{C}$ substrates resulting from the rapid consumption of labile $\mathrm{C}$ at the initial stage. Microorganisms are classified as r-strategists and $\mathrm{K}$-strategists based on their survival competitiveness. The former grow rapidly when easily available substrates are abundant at the cost of low population stability, while the latter are adapted to using limited resources more efficiently and survive for a longer time (Andrews and Harris, 1986). Therefore, at the initial stage, the r-strategists would have dominated the community when the wastewater was rich in easily available C. However, with the decomposition of SWOC, the r-strategists would have gradually died out, while the $\mathrm{K}$-strategists capable of surviving on stable organic $\mathrm{C}$ would have outgrown the former, leading to a decrease in the microbial functional diversity. The initial ratio between $\mathrm{r}$-strategists and $\mathrm{K}$-strategists in wastewater $\mathrm{H}$ might have been higher than that in wastewater L. Thus, the elimination of r-strategists would have brought a greater effect on the microbial functional diversity of wastewater $\mathrm{H}$, resulting in a significant decrease in the $\mathrm{H}^{\prime}$ and $\mathrm{D}$ in the last two stages. Altogether, the microbial functional diversity for the two types of wastewaters with different amounts of organic $\mathrm{C}$ showed the same downtrend during SWOC mineralization, and the functional diversity might be less stable for wastewater containing higher amount of organic $\mathrm{C}$ and nutrients.

The initial microbial metabolic profiles in both the types of wastewaters were much similar regardless of their difference in the community structures, indicating a strong functional similarity in raw wastewater (Allison and Martiny, 2008). As the diversity of C sources decreased during SWOC mineralization and the level of recalcitrant $\mathrm{C}$ increased, the microorganisms dependent on certain $\mathrm{C}$ sources would have perished (Tiquia, 2010), contributing to the difference in the metabolic profiles among the three mineralization stages. In other words, each mineralization stage was driven by specific microbial functional group. According to mantel test and CCA analysis, SUVA $_{254}$ was the most significant driving factor, suggesting that $\mathrm{C}$ availability and competition between the $r$-strategists and $\mathrm{K}$-strategists might also be responsible for the shifts in the microbial metabolic profile during SWOC mineralization. Moreover, the importance of $\mathrm{pH}$ could not be neglected. As the optimal range of $\mathrm{pH}$ for bacterial growth is only 3 to 4 (Rosso et al., 1995; Rousk et al., 2010), the wastewater bacterial community can be quite sensitive to the significant shift in $\mathrm{pH}$ during SWOC mineralization. Besides, the changes in the $\mathrm{pH}$ might alter the amount and composition of wastewater DOC (Andersson et al., 2000; Spencer et al., 2007), and thus, the $\mathrm{C}$ utilization ability of the microorganisms. Therefore, $\mathrm{pH}$ is a comprehensive predictor that indicates the impacts of various chemical properties on wastewater microbial metabolic profile.

In addition to $\mathrm{SUVA}_{254}, \mathrm{C} / \mathrm{N}$ also had a major influence on swine wastewater bacterial diversity. Swine wastewater is characterized by large amounts of N. For the two tested wastewaters, the $\mathrm{C} / \mathrm{N}$ remained far below the average value (which is 5) for bacteria cells (Fagerbakke et al., 1996) throughout the SWOC mineralization process, resulting in $\mathrm{C}$ insufficiency and limited bacterial growth. 
In the initial stage, $\mathrm{C} / \mathrm{N}$ was at its peak and closest to the optimum value for bacterial growth, and thus, maximum diversity of wastewater bacteria was noted. The slight increase in the diversity indices in the last two stages of the mineralization process could be attributed to the increase in $\mathrm{C} / \mathrm{N}$, which suggested a relief from $\mathrm{C}$ insufficiency. Thus, a combination of these two factors indicated the significant effects of the relative amount and bio-availability of organic $\mathrm{C}$ on swine wastewater bacterial diversity.

The dynamics of bacterial community structure is driven by $\mathrm{SUVA}_{254}$. According to previous studies, the aromaticity of DOC is the primary driving factor of bacterial community structure in ecosystems such as soil (Marschner, 2003). The intensified toxicity resulting from the accumulation of aromatic OM (Northupet al., 1998) and their resistance to metabolism might be the main reasons for the shifts in the bacterial community structure. Instead of $\mathrm{C} / \mathrm{N}$, which significantly correlates to wastewater bacterial diversity, TDN has been noted to be one of the most indicators of the bacterial community structure. In fact, species diversity and community structure do not correspond to each other. The former is a function of the relative frequency of different species (Keylock, 2005), while the latter represents the composition information of a certain community. In other words, equivalent diversities do not necessarily refer to the same community structures, whereas different community structures might show identical species diversities. Therefore, the effect of $\mathrm{C} / \mathrm{N}$ on bacterial diversity might be attributed to its influence on the relative abundance of individual species. However, TDN might probably exert a greater effect on the species composition of bacterial community under the stress of continuous decline in $\mathrm{C}$ bio-availability.

\section{CONCLUSIONS}

Swine wastewater organic carbon mineralization was characterized by rapid decomposition of labile carbon and subsequent mineralization of recalcitrant carbon. The relative quantity of the labile and recalcitrant carbon pools, and their mineralization processes differed between wastewaters with different organic carbon concentrations, suggesting that corresponding measures should be taken according to the differences in wastewaters to harness their effects on agricultural soils. The bacteria in raw wastewaters exhibited functional similarity, and both metabolic profile and community structure changed with the mineralization of swine wastewater organic carbon. This shift was mainly driven by the reduced bio-availability of dissolved organic carbon. These findings would facilitate the evaluation of the effects of wastewater application on soil organic carbon and microbial dynamics.

\section{ACKNOWLEDGEMENTS}

This study was jointly supported by funding from the Special Fund for Agro-scientific Research in the Public Interest of China (201203050-3) and the National Natural Science Foundation of China (nr 41171233). We thank Associate Prof. F.X. Han, for his constructive comments on the early version of this manuscript, which greatly improved the quality of our article.

\section{LITERATURE CITED}

Adeli, A., C.H. Bolster, D.E. Rowe, M.R. McLaughlin, and G.E. Brink. 2008. Effect of long-term swine effluent application on selected soil properties. Soil Science 173:223-235.

Allison, S.D., and J.B. Martiny. 2008. Resistance, resilience, and redundancy in microbial communities. Proceedings of the National Academy of Sciences 105:11512-11519.

Andersson, S., S.I. Nilsson, and P. Saetre. 2000. Leaching of dissolved organic carbon (DOC) and dissolved organic nitrogen (DON) in mor humus as affected by temperature and $\mathrm{pH}$. Soil Biology \& Biochemistry 32:1-10.

Andrews, J.H., and R.F. Harris. 1986. r- and K-selection and microbial ecology. Advances in Microbial Ecology 9:99-147.

Bernet, N., and F. Béline. 2009. Challenges and innovations on biological treatment of livestock effluents. Bioresource Technology 100:5431-5436.

Borcard, D., F. Gillet, and P. Legendre. 2011. Numerical ecology with R. Springer, New York, USA.

Chin, Y.-P., G.R. Aiken, and K.M. Danielsen. 1997. Binding of pyrene to aquatic and commercial humic substances: The role of molecular weight and aromaticity. Environmental Science \& Technology 31:1630-1635.

Cook, K.L., M.J. Rothrock, Jr., N. Lovanh, J.K. Sorrell, and J.H. Loughrin. 2010. Spatial and temporal changes in the microbial community in an anaerobic swine waste treatment lagoon. Anaerobe 16:74-82.

Deng, L.W., C.D. Cai, and Z.A. Chen. 2007. The treatment of pig slurry by a full-scale anaerobic-adding raw wastewater-intermittent aeration process. Biosystems Engineering 98:327-334.

Deng, L.W., P. Zheng, Z.A. Chen, and Q. Mahmood. 2008. Improvement in post-treatment of digested swine wastewater. Bioresource Technology 99:3136-3145.

Dinuccio, E., W. Berg, and P. Balsari. 2008. Gaseous emissions from the storage of untreated slurries and the fractions obtained after mechanical separation. Atmospheric Environment 42:2448-2459.

Fagerbakke, K.M., M. Heldal, and S. Norland. 1996. Content of carbon, nitrogen, oxygen, sulfur and phosphorus in native aquatic and cultured bacteria. Aquatic Microbial Ecology 10:15-27.

Fangueiro, D., H.M. Ribeiro, E. Vasconcelos, J. Coutinho, and F. Cabral. 2012. Influence of animal slurries composition and relative particle size fractions on the $\mathrm{C}$ and $\mathrm{N}$ mineralization following soil incorporation. Biomass and Bioenergy 47:50-61.

Fernandes, G.W., A. Kunz, R.L.R. Steinmetz, A. Szogi, M. Vanotti, É.M. de Moraes Flores, et al. 2012. Chemical phosphorus removal: A clean strategy for piggery wastewater management in Brazil. Environmental Technology 33:1677-1683.

Fernández, J.M., C. Plaza, D. Hernández, and A. Polo. 2007. Carbon mineralization in an arid soil amended with thermally-dried and composted sewage sludges. Geoderma 137:497-503.

García-Gil, J.C., C. Plaza, P. Soler-Rovira, and A. Polo. 2000. Longterm effects of municipal solid waste compost application on soil enzyme activities and microbial biomass. Soil Biology and Biochemistry 32:1907-1913.

Gigliotti, G., K. Kaiser, G. Guggenberger, and L. Haumaier. 2002. Differences in the chemical composition of dissolved organic matter from waste material of different sources. Biology and Fertility of Soils 36:321-329. 
Girard, M., J. Nikiema, R. Brzezinski, G. Buelna, and M. Heitz. 2009. A review of the environmental pollution originating from the piggery industry and of the available mitigation technologies: Towards the simultaneous biofiltration of swine slurry and methane. Canadian Journal of Civil Engineering 36:1946-1957.

González, C., J. Marciniak, S. Villaverde, P.A. García-Encina, and R. Muñoz. 2008. Microalgae-based processes for the biodegradation of pretreated piggery wastewaters. Applied Microbiology Biotechnology 80:891-898.

Ibekwe, A.M., C.M. Grieve, and S.R. Lyon. 2003. Characterization of microbial communities and composition in constructed dairy wetland wastewater effluent. Applied and Environmental Microbiology 69:5060-5069.

Keylock, C.J. 2005. Simpson diversity and the Shannon-Wiener index as special cases of a generalized entropy. Oikos 109:203-207.

Kim, W., K. Hwang, S.G. Shin, S. Lee, and S. Hwang. 2010. Effect of high temperature on bacterial community dynamics in anaerobic acidogenesis using mesophilic sludge inoculum. Bioresource Technology 101:S17-S22.

Marschner, P. 2003. Structure and function of the soil microbial community in a long-term fertilizer experiment. Soil Biology and Biochemistry 35:453-461.

Molina, J.A.E., C.E. Clapp, and W.E. Larson. 1980. Potentially mineralizable nitrogen in soil: The simple exponential model does not apply for the first 12 weeks of incubation. Soil Science Society of America Journal 44:442-443.

Mota, C., M.A. Head, J.A. Ridenoure, J.J. Cheng, and F.L. de Los Reyes, 2005. Effects of aeration cycles on nitrifying bacterial populations and nitrogen removal in intermittently aerated reactors. Applied and Environmental Microbiology 71:8565-8572.

Murphy, J., and J.P. Riley. 1962. A modified single solution method for the determination of phosphate in natural waters. Analytica Chimica Acta 27:31-36.

Muyzer, G., T. Brinkhoff, U. Nübel, C. Santegoeds, H. Schäfer, and C. Wawer. 1998. Denaturing gradient gel electrophoresis (DGGE) in microbial ecology. p. 1-27. In Akkermans, A.D.L., J.D. van Elsas, and F.J. de Bruijn (eds.) Molecular microbial ecology manual. Kluwer Academic Publishers, Dordrecht, The Netherlands.

Muyzer, G., E.C. de Waal, and A.G. Uitterlinden. 1993. Profiling of complex microbial populations by denaturing gradient gel electrophoresis analysis of polymerase chain reaction-amplified genes coding for $16 \mathrm{~S}$ rRNA. Applied and Environmental Microbiology 59:695-700
Muyzer, G., A. Teske, C.O. Wirsen, and H.W. Jannasch. 1995. Phylogenetic relationships of thiomicrospira species and their identification in deep-sea hydrothermal vent samples by denaturing gradient gel electrophoresis of $16 \mathrm{~S}$ rDNA fragments. Archives of Microbiology 164:165-172.

Northup, R., R. Dahlgren, and J. McColl. 1998. Polyphenols as regulators of plant-litter-soil interactions in northern California's pygmy forest: A positive feedback? Biogeochemistry 42:189-220.

Pajączkowska, J., A. Sulkowska, W.W. Sulkowski, and M. Jedrzejczyk. 2003. Spectroscopic study of the humification process during sewage sludge treatment. Journal of Molecular Structure 651-653:141-149.

Patil, S.S., M.S. Kumar, and A.S. Ball. 2010. Microbial community dynamics in anaerobic bioreactors and algal tanks treating piggery wastewater. Applied Microbiological Biotechnology 87:353-363.

Rosso, L., J.R. Lobry, S. Bajard, and J.P. Flandrois. 1995. Convenient model to describe the combined effects of temperature and $\mathrm{pH}$ on microbial growth. Applied and Environmental Microbiology 61:610-616.

Rousk, J., E. Baath, P.C. Brookes, C.L. Lauber, C. Lozupone, J.G. Caporaso, et al. 2010. Soil bacterial and fungal communities across a pH gradient in an arable soil. ISME Journal 4:1340-1351.

Spencer, R.G.M., L. Bolton, and A. Baker. 2007. Freeze/thaw and $\mathrm{pH}$ effects on freshwater dissolved organic matter fluorescence and absorbance properties from a number of UK locations. Water Research 41:2941-2950.

Tiquia, S.M. 2010. Metabolic diversity of the heterotrophic microorganisms and potential link to pollution of the Rouge River. Environmental Pollution 158:1435-1443.

Walsh, J., J. Rousk, G. Edwards-Jones, D. Jones, and A.P. Williams. 2012. Fungal and bacterial growth following the application of slurry and anaerobic digestate of livestock manure to temperate pasture soils. Biology and Fertility of Soils 48:889-897.

Weishaar, J.L., G.R. Aiken, B.A. Bergamaschi, M.S. Fram, R. Fujii, and K. Mopper. 2003. Evaluation of specific ultraviolet absorbance as an indicator of the chemical composition and reactivity of dissolved organic carbon. Environmental Science \& Technology 37:4702-4708

Zhou, Z.G., Z.P. Li, Y.Q. He, and X.X. Wang. 2013. Scale pig farming and its impacts on soil and water environment in red soil hilly regions: A case study of Yujiang County, Jiangxi Province, China. Acta Pedologica Sinica 50:703-711. 